Scaup on October 11; >175 Common Goldeneye on November 1; > 75 Bufflehead on October 11; $420 \pm$ Ruddy Ducks on September 20; 115 Whiterumped Sandpipers on May $31 ; 105$ Sanderlings on May 31 ; and > 35 Bonaparte's Gulls on October 11. Other high counts were $>12$ Semipalmated Plover on May 19; 6 Piping Plover on May 5; 53 Black-bellied Plover on May 24; 32 Willets on August 30; 86 Greater Yellowlegs on September 20; 7 Knots on May 24; 173 Marbled Godwits on August 23; $>200$ Barn Swallows on September 7; 3 Mourning Warblers on May 24; 10 Yellowthroats on May 28, and $100 \pm$ Common Grackles on September 6 .

Stragglers and Rarities: Thirty-four species were reported on only one or two days during the 12-month period. There was a single bird on each date unless otherwise noted in parentheses. Blue Goose, April 13 (4) and 20 (2); Black Duck, August 20; White-winged Scoter, June 22 (4) and November 8; Hooded Merganser, September 20 (4); Turkey Vulture, April 13; Goshawk, November 1; Prairie Falcon. October 27; Peregrine Falcon, August 3 and 31; Whooping Crane, October 4 (9); Virginia Rail, June 13; Dunlin, May 19 and 24 (2); Buff-breasted Sandpiper, May 23 (3) and $24(25+)$; Hudsonian
Godwit, April 28 and May 23; Forster's Tern, October 11; Hawk Owl, January 5 and March 8; Boreal Owl, February 10; Red-shafted Flicker, April 6 and June 28; Traill's Flycatcher, June 3 (3) and 6; Olive-sided Flycatcher, May 24 and June 6; Purple Martin, May 24 (4); White-breasted Nuthatch, December 26; Long-billed Marsh Wren, May 24; Short-billed Marsh Wren, May 24; Mockingbird, October 6; Townsend's Solitaire, October 13; Nashville Warbler, May 15 and 16; Blackburnian Warbler, October 13; Chestnut-sided Warbler, September 7; Bay - breasted Warbler, October 6; Mourning Warbler, May 24 and 28; Canada Warbler, August 20 and September 19; Grasshopper Sparrow, May 24; Sharp-tailed Sparrow, July 13 and 14 (4), and McCown's Longspur, May 24 (11).

Miscellaneous: There was a new species for the district: a Varied Thrush in the city on October 8, 10 and 11.

An orange-dyed swan (from Chesapeake Bay) was seen migrating northwest on May 4 and four dyed birds spent several days in May on a slough on the city's outskirts. Two partial albino Myrtle Warblers were reported, one on May 17 and one on October 5.

\title{
UNUSUALLY LARGE NUMBERS OF ROSS' GEESE OBSERVED AT LAST MOUNTAIN LAKE
}

\section{by F. W. Lahrman, Saskatchewan Museum of Natural History, Regina}

On September 27, 1970, I observed flocks of Ross' Geese departing from the north end of Last Mountain Lake near Watertown during their evening flight to the stubble fields to feed. In past years, I have seen a few individuals or small flocks numbering up to 50 birds. (See Blue Jay 15:165, December, 1961). This evening, however, I estimated the total of birds in flocks that passed by close enough for identification to be well over 1,000 . I counted 300 in one flock, but the usual number per flock was 30 to 50 . Most of the
Ross's were flying in flocks of their own species, but a few were accompanied by White-fronts or Snows, and at times, a few Ross's accompanied flocks of White-fronts.

It is interesting to note that on this date, eight Ross' Geese were also seen at Deep Lake (five miles south of Indian Head) by Lorne Scott. From previous observations, we consider Deep Lake to be a very important breeding and resting area for a great variety of waterfowl, and it is to be hoped that it will remain a protected 
area for wildlife the year around.

On October 3rd and 4th, I again saw Ross' Geese on Last Mountain Lake, west of Govan, though in somewhat fewer numbers than those observed on September 27. This may simply mean that I was not in an area where the majority were resting. John Hatfield, Project Manager of the Last Mountain Lake Wildlife Refuge, has since told me that he also observed unusually large numbers of Ross' Geese at the north end of the lake from September 20 to October 10, 1970. Most of the geese left the area October 8 during a weather front moving in from the northwest with strong, gusty winds.

I was aided in the identification of the Ross' Geese by their call which is quite distinctive from that of the other species, and I was fortunate enough to obtain a tape recording of their voices.

\section{POSSIBLE WILD HYBRID OF THE WHITE-FRONTED $X$ SNOW GOOSE}

by F. W. Lahrman, Saskatchewan Museum of Natural History, Regina

On October 4, 1970, while observing geese and cranes at the north end of Last Mountain Lake, northwest of Govan, I noticed a strange colored goose flying with a flock of approximately 35 White-fronted Geese around 10:00 a.m. The flock alighted on a stubble field only one-quarter of a mile away, where I was able to observe this goose with a $30 \mathrm{x}$ telescope. On checking later, I was surprised to note that it had a marked similarity to the two geese described by Alex Dzubin of the Canadian Wildlife Service (Blue Jay, $22: 101-107$ ).

\section{Description of the Goose}

Silhouette, size, head, bill, neck and body proportions appeared to be similar to that of the White-fronts; bill orange; head and neck - dark gray; broad white forehead patch and a light cheek patch. The gray of the neck fused into a white breast near the base of the neck; entire underparts-white. The back from base of tail almost to base of wings - white (observed when bird was in flight). At rest, the bird appeared to be gray above and white below. The tail was dark gray. The wings appeared to be similar to those of the White-fronts. I was unable to see the color of the legs or to determine whether it had a dark grinning patch on the bill such as the Snow Geese have.

I do not think that this was a partial albino White-front because the darker colors were slate-gray rather than the gray-brown of the Whitefronts.

Several Snow and Blue Geese were observed in the area but they were not associated with this flock.

\section{Information Wanted on Colour-marked Bald Eagles}

As part of a project designed to learn more about the migration of Saskatchewan's Bald Eagles, the tails of 16 nestlings were painted orange this past summer. If you see or hear of one of these marked eagles, please contact D. Whitfield, 415 10th Street E., Saskatoon.

\section{FIELD NOTES REPORTS}

The new regional editor for AUDUBON FIELD NOTES is C. Stuart Houston, 863 University Drive, Saskatoon. All birdwatchers on the prairies are asked to submit their seasonal observations regularly to allow an overall picture of bird distribution and abundance. Notes on the common species with dates and numbers are more desirable than observations of rarities. Data on fall migration are due December 10, winter season April 10, spring migration June 10 and nesting season August 10.

\section{NEST RECORD CARDS}

Please send Prairie Nest Record Cards in to the Prairie Nest Records Scheme, c/o The Manitoba Museum of Man and Nature, 190 Rupert Avenue, Winnipeg 2, Manitoba, as soon as possible, so that the 1970 summary can be prepared. 